Published in final edited form as:

Am J Physiol Cell Physiol. 2007 January ; 292(1): C564-C572.

\title{
POTENTIATION OF INSULIN-STIMULATED GLUCOSE TRANSPORT BY THE AMP-ACTIVATED PROTEIN KINASE
}

\author{
Jeong-Sun Ju, Michael A. Gitcho, Carter A. Casmaer, Pankaj B. Patil, Dae-Gyue Han, Susan \\ A. Spencer, and Jonathan S. Fisher \\ Department of Biology, Saint Louis University, St. Louis, MO 63103, USA
}

\section{Abstract}

Data from the use of activators and inhibitors of the AMP-activated protein kinase (AMPK) suggest that AMPK increases sensitivity of glucose transport to stimulation by insulin in muscle cells. We assayed insulin action after adenoviral transduction of constitutively active (Ad-AMPK-CA, a truncated form of AMPK $\alpha 1$ ) and dominant negative (Ad-AMPK-DN, that depletes endogenous $\mathrm{AMPK} \alpha$ ) forms of AMPK $\alpha$ into C2C12 myotubes. Compared with control (Ad-GFP), Ad-AMPK$\mathrm{CA}$ increased the ability of insulin to stimulate glucose transport. The increased insulin action in cells expressing AMPK-CA was suppressed by Compound C (an AMPK inhibitor). Exposure of cells to AICAR (an AMPK activator) increased insulin action in uninfected myotubes and myotubes transduced with GFP but did not increase insulin action in Ad-AMPK-DN myotubes. Ad-AMPKCA transduced cells had decreased serine phosphorylation of IRS-1 at an mTOR (or SK6) target site that is reportedly associated with insulin resistance. These data suggest that in myotubes, activated AMPK $\alpha 1$ is sufficient to increase insulin action and that presence of functional AMPK $\alpha$ is necessary to AICAR-related increases in insulin action.

\section{Introduction}

For nearly a decade, there has been intense scrutiny of the role of the AMP-activated protein kinase (AMPK) in the insulin-independent stimulation of glucose transport in skeletal muscle $(7 ; 13 ; 24 ; 32)$. In contrast, there has been relatively little examination of the possibility that AMPK activation acutely increases the susceptibility of glucose transport to stimulation by insulin. For example, although it is known that treatment of muscle or myotubes with AICAR (an AMPK activator) potentiates insulin action and that Compound C (an AMPK inhibitor) prevents the increase in insulin-stimulated glucose transport that occurs after exposure of myotubes to hyperosmotic medium (an AMPK-activating treatment) $(5 ; 16 ; 35)$, it is still not entirely clear whether or not AMPK regulates insulin action (4).

Neither whole-body knockout of the $\alpha 2$ catalytic subunit of AMPK nor muscle-specific expression of an inactive AMPK $\alpha 2$ form that depletes endogenous AMPK $\alpha 1$ and AMPK $\alpha 2$ affects insulin responsiveness (glucose transport stimulated by a maximally-effective concentration of insulin) in isolated skeletal muscle $(26 ; 38)$. However, whether insulin sensitivity was decreased (i.e. a rightward shift in the insulin dose-response curve, with an increase in the insulin concentration required to achieve a given level of glucose transport) in AMPK $\alpha$ deficient muscle or cells has not been addressed. The distinction between insulin responsiveness and insulin sensitivity in regard to potential effects of AMPK is important, because exercise, that has been suggested to act through AMPK to increase insulin sensitivity (5), does not necessarily affect insulin responsiveness (9;10). Additionally, to determine

Corresponding Author: Jonathan S. Fisher, Department of Biology, Saint Louis University, 3507 Laclede Ave, St. Louis, MO 63103, USA; Tel. 314-977-1712;Fax. 314-977-3658; E-mail: fisherjs@ SLU.edu. 
whether AMPK knockout or depletion has effects on insulin sensitivity, it would be necessary to assess insulin sensitivity after an AMPK-activating treatment.

Recent studies have demonstrated a link between the AMPK and mammalian target of rapamycin (mTOR) signaling pathways $(20 ; 22 ; 29 ; 37)$. For example, incubation with AICAR inhibits p70 S6 kinase (S6K, an mTOR effector) activity in mammalian cells (21). Once activated, AMPK phosphorylates tuberous sclerosis complex 2 (TSC2), leading to suppression of mTOR/S6K signaling $(17 ; 18)$. When activated, mTOR/S6K represses insulin receptor substrate (IRS-1)-related signaling via both a transcriptional repression of IRS-1 gene expression mediated by S6K and direct phosphorylation of IRS-1 protein by mTOR or S6K (14).

We hypothesized that AMPK regulates insulin action in $\mathrm{C} 2 \mathrm{C} 12$ myotubes. We assayed insulinstimulated glucose transport after use of adenovirus-mediated gene transfer to express constitutive active (Ad-AMPK-CA) and dominant negative (Ad-AMPK-DN) forms of AMPK $\alpha$ or green fluorescent protein (Ad-GFP) as a control. In addition, we examined whether the regulation of insulin signaling by AMPK was associated with mTOR signaling.

\section{Methods}

\section{Materials}

A polyclonal antibody specific for the GLUT4 glucose transporter was the generous gift of Dr. Mike Mueckler (Washington University, St. Louis, MO). Horseradish peroxidase-conjugated goat anti-rabbit IgG was purchased from Pierce Biotechnology (Rockford, IL). An antibody against GAPDH was obtained from Novus Biologicals (Littleton, CO). Isoform-specific AMPK $\alpha$ antibodies were purchased from Upstate USA (Charlottesville, VA). Antibodies against phosphorylated acetyl-CoA carboxylase (P-ACC) (Ser79), mTOR, P-p70S6k (Thr389), p70S6k, P-IRS-1 (Ser636/639), IRS-1, P-Akt (Ser 473 and Thr308), Akt, P-AMPK, AMPK, and myc epitope were purchased from Cell Signaling Technology (Beverly, MA). Phosphospecificity of antibodies was determined by the producer (Cell Signaling Technology, Danvers, MA) using induction systems (e.g. treatment with insulin) and treatment of samples with calf intestinal phosphatase (for P-AMPK, P-Akt-Thr308, P-IRS-1-Ser636/639), treatment of samples with lambda phosphatase (P-ACC), or use of an Akt S473A mutant, that is not detectable with the antibody against P-Akt-Ser473. 2 -deoxy -D-[1,2- $\left.{ }^{3} \mathrm{H}(\mathrm{N})\right]$-glucose (2-DG) was from American Radiolabeled Chemicals (St. Louis, MO), and purified porcine insulin was from Eli Lilly (Indianapolis, IN). AICAR was purchased from Toronto Research Chemicals (North York, ON), and Compound C was generously provided by Merck (Rahway, NJ). All other reagents were obtained from Sigma Chemical (St. Louis, MO).

Cell culture and adenovirus infection-The mouse myoblast cell line $\mathrm{C} 2 \mathrm{C} 12$ (American Type Culture Collection, Rockville, $\mathrm{MD}$ ) was maintained at $37^{\circ} \mathrm{C} / 5 \% \mathrm{CO}_{2}$ in low glucose Dulbecco's modified Eagle's medium (DMEM; Washington University School of Medicine Tissue Culture Support Center, St. Louis, MO) supplemented with $10 \%$ fetal bovine serum, $50 \mu \mathrm{g} / \mathrm{ml}$ penicillin, and $50 \mu \mathrm{g} / \mathrm{ml}$ streptomycin. Cultures were induced to differentiate in DMEM containing $2 \%$ horse serum. The AMPK-CA adenoviral vector (a generous gift from Dr. Kenneth Walsh, Boston University School of Medicine, Boston, MA) was constructed from a rat cDNA encoding residues 1-312 of AMPK $\alpha 1$ and bearing a mutation of threonine 172 into aspartic acid (T172D) as described previously (39). The AMPK-DN adenoviral vector (constructed by Morris Birnbaum, University of Pennsylvania, Philadelphia, PA) was constructed from AMPK $\alpha 2$ bearing a mutation of lysine 45 to arginine (K45R) as described previously (26;27;41). Adenoviruses were amplified into 293 cells and purified using cesium chloride ultracentrifugation. The viruses were desalted using PD-10 columns and virus titer was determined by measuring the optical density at $260 \mathrm{~nm}$. Four days after differentiation, 
mature $\mathrm{C} 2 \mathrm{C} 12$ myotubes were infected with adenoviruses at $100 \mathrm{pfu} / \mathrm{cell}$ for 48 -h. All experiments were performed 2 days after infection.

2-Deoxyglucose transport-Glucose uptake into $\mathrm{C} 2 \mathrm{C} 12$ myotubes was measured using radiolabeled 2-deoxy-D-[1-3 $\mathrm{H}]$ glucose, as described previously (35). Before glucose transport assays, cells were washed twice with HEPES-buffered saline (HBS). Glucose transport assays were performed by incubating cells with HBS containing radiolabeled 2-deoxyglucose $(3 \mu \mathrm{Ci} /$ $\mathrm{ml}$ ) and unlabeled $10 \mu \mathrm{M}$ 2-DG at room temperature. If cells had previously been exposed to insulin (see below), insulin was included in the glucose uptake assay medium. After $10 \mathrm{~min}$, 2-deoxyglucose uptake was terminated by three quick washes with ice-cold $0.9 \%$ saline. Cells were lysed in $0.2 \mathrm{~N} \mathrm{NaOH}$ containing $0.2 \%$ SDS, and then ${ }^{3} \mathrm{H}$ was counted by a liquid scintillation spectrophotometer. Data are presented as picomoles of 2-deoxy- $\left[{ }^{3} \mathrm{H}\right]$ glucose per milligram protein per minute.

To determine the effect of Ad-AMPK-CA on 2-DG glucose transport, on the day of the experiment, myotubes were serum starved for $3 \mathrm{~h}$ and then incubated for 20 min with 0,10 or $100 \mathrm{nM}$ insulin before 2-deoxyglucose transport assays as described above. In our hands, 10 $\mathrm{nM}$ insulin is near the threshold insulin concentration for stimulation of glucose transport in C2C12 myotubes (35;36). To examine the effects of Ad-AMPK-CA and compound C [an AMPK inhibitor (40)] on glucose uptake, myotubes were preincubated for $3 \mathrm{~h}$ in the absence or presence of $20 \mu \mathrm{M}$ compound $\mathrm{C}$ in serum-free DMEM. Glucose transport assays were performed after a 20-min preincubation of myotubes in the absence or presence of 10 or 100 $\mathrm{nM}$ insulin. Compound $\mathrm{C}$ was intentionally left out of the glucose transport media with the expectation that the $3 \mathrm{~h}$ of incubation with Compound $\mathrm{C}$ (not the presence of Compound $\mathrm{C}$ during glucose transport, per se) would be sufficient to prevent the potentiating effect of AMPK-CA on insulin-stimulated glucose transport. We did not include Compound $\mathrm{C}$ in the rinses before glucose transport or during glucose transport assays, because we did not want the insulin-independent effects of AMPK-CA on glucose transport to be inhibited.

To assess the effects of Ad-AMPK-DN expression and AICAR stimulation on glucose uptake, myotubes (uninfected or transduced with GFP or AMPK-DN) were pretreated with $0.5 \mathrm{mM}$ AICAR for $1 \mathrm{~h}$ in medium containing $2 \%$ horse serum. Then myotubes were allowed to recover for $4 \mathrm{~h}$ in serum-free medium. After recovery incubations, myotubes were preincubated in the absence or presence of $10 \mathrm{nM}$ insulin. Then, 2-DG uptake was measured in myotubes as described above. AICAR was deliberately excluded from the recovery medium after the $1 \mathrm{~h}$ incubation with AICAR to allow the immediate effects of AICAR to decrease over the recovery period. We based this model of AICAR treatment followed by recovery before exposure to insulin on what is known about exercise-induced increases in insulin action. The insulinsensitizing effect of exercise is robust a few hours after exercise $(5 ; 10 ; 25)$, but not necessarily during or immediately after exercise (28).

Immunofluorescence and confocal microscopy-C2C12 cells plated on glass coverslips were fixed with $4 \%$ paraformaldehyde for $10 \mathrm{~min}$ at room temperature. Then, the cells were permeabilized with $0.1 \%$ Triton X-100/phosphate buffered saline (PBS) for $7 \mathrm{~min}$ at room temperature. After blocking nonspecific binding sites in $3 \%$ bovine serum albumin (BSA)/PBS for $1 \mathrm{~h}$ at room temperature, the cells were incubated with Glut- 4 antibody at a 1:100 dilution in buffer A (PBS containing 0.05\% Tween 20 and $1 \% \mathrm{BSA}$ ) for $1 \mathrm{~h}$ at room temperature. After washing with PBS, the cells were incubated with Cy3-conjugated goat antirabbit IgG (Jackson ImmunoResearch Laboratories, Inc., West Grove, PA) at a 1:200 dilution in buffer $\mathrm{A}$ for $1 \mathrm{~h}$ at room temperature. Subsequently, the cells were extensively washed with buffer A and mounted onto glass slides. The specimens were examined with LSM 5 PASCAL confocal microscopy (Carl Zeiss, Jena, Germany) for fluorescence of GFP and/or Cy3. 
Western blot analysis- $\mathrm{C} 2 \mathrm{C} 12$ cells grown on six-well plates were washed with ice-cold PBS and then scraped into homogenizing buffer containing $50 \mathrm{mM}$ HEPES, $\mathrm{pH} 7.4,150 \mathrm{mM}$ $\mathrm{NaCl}, 10 \%$ glycerol, $1 \%$ Triton X-100, $1.5 \mathrm{mM} \mathrm{MgCl}_{2}, 1 \mathrm{mM}$ EDTA, $10 \mathrm{mM} \mathrm{Na}_{3} \mathrm{PO}_{4}, 100$ $\mathrm{mM} \mathrm{NaF}, 2 \mathrm{mM} \mathrm{Na} \mathrm{VO}_{4}, 10 \mu \mathrm{g} / \mathrm{ml}$ leupeptin, $10 \mu \mathrm{g} / \mathrm{ml}$ aprotinin, and $1 \mathrm{mM}$ phenylmethylsulfonyl fluoride. Lysates were centrifuged at $14,000 \mathrm{rpm}$ for $10 \mathrm{~min}$. Soluble proteins were quantitated using the bicinchoninic acid kit (Pierce Chemical Co., Rockford, IL) with BSA as a standard and adjusted to $1 \mu \mathrm{g} / \mu \mathrm{l}$. Aliquots of homogenate were solubilized in Laemmli sample buffer and $50 \mu \mathrm{g}$ of protein subjected to SDS-PAGE (10\% resolving gel). Proteins were transferred to nitrocellulose membranes (Hybond ${ }^{\mathrm{TM}}$-ECL $^{\mathrm{TM}}$, Amersham Biosciences). Membranes were blocked in a solution of Tris-buffered saline containing 5\% nonfat dry milk. Myc epitop was detected by incubation of blots with a 1:5,000 dilution of myc tag antibodies and followed by horseradish peroxidase-conjugated anti-mouse IgG. Protein was visualized using ECL. Western blots for P-ACC (Ser79), P-p70S6k (Thr389), p70S6k, PIRS-1 (Ser636/639), IRS-1, P-Akt (Ser 473 and Thr308), Akt were performed in an analogous method as described above. GAPDH content of myotubes was also determined. GLUT4 content was detected by incubation of blots with a 1:5,000 dilution of rabbit polyclonal antisera raised against the $\mathrm{COOH}$ terminus of GLUT4 followed by horseradish peroxidase-conjugated anti-rabbit IgG.

Assay of endogenous AMPKa-Because DN-AMPK and endogenous AMPK $\alpha$ migrated to overlapping positions on our mini-gels, we performed an immunodepletion of DN-AMPK (a myc-tagged construct) before assessing the levels of remaining (i.e. endogenous)

AMPK $\alpha 1$ and $\alpha 2$. Antibodies against myc tag ( $14 \mu \mathrm{g} /$ sample) were incubated with protein A sepharose, washed several times with phoshphate-buffered saline, and then incubated with myotube lysates. Beads were pelleted by centrifugation, and residual AMPK $\alpha$ and myc-tagged proteins in immunodepleted supernatants were assessed by western blot. For the western blot against myc tag, a non-immunodepleted sample from Ad-AMPK-DN cells (loaded with the same amount of protein as immunodepleted samples) was used as a positive control.

Statistics-Analyses were performed by ANOVA followed by Fisher LSD posthoc comparisons only when ANOVAs yielded $\mathrm{P}<0.05$. For western blots of AMPK, P-ACC, mTOR, S6K, P-S6K, IRS-1, P-IRS-1, Akt, and P-Akt, there were 16 samples per group. For GLUT4 western blots, there were 12 samples per group. Group Ns for glucose transport assays are shown in the figure legends.

\section{Results}

\section{Expression of Ad-GFP, AD-AMPK-CA and AD-AMPK-DN in C2C12 myotubes}

Confocal microscopic examination demonstrated that control Ad-GFP was uniformly expressed within 48 hours after incubation of $\mathrm{C} 2 \mathrm{C} 12$ myotubes with the adenoviral vector (Fig. 1A). Western blot analysis of lysates from myotubes expressing myc-tagged Ad-AMPK-CA and Ad-AMPK-DN (Fig. 1B), using anti-myc tag antibody as a probe, showed bands at $\sim 30$ $\mathrm{kDa}$ (Ad-AMPK-CA, a truncated form of AMPK $\alpha$ ) and $\sim 65 \mathrm{kDa}$ (Ad-AMPK-DN). Expression of AMPK $\alpha$ protein was determined by immunoblotting with AMPK $\alpha$ antibody (Fig.1B). Endogenous AMPK $\alpha$ and Ad-AMPK-DN were detected at $\sim 60 \mathrm{kDa}$, and there was also a band at $\sim 30 \mathrm{kDa}$ from cells transduced with Ad-AMPK-CA. After immunodepletion of myc-tagged AMPK $\alpha$, it was possible to assess the amount of endogenous AMPK $\alpha$ : AMPK $\alpha 2$ was not present in myotubes transduced with Ad-AMPK-DN, and AMPK $\alpha 1$ content was drastically reduced (fig 1C). It appeared that the immunoprecipitation completely immunodepleted myctagged protein from the samples, because there was no AMPK $\alpha 2$ (the myc-tagged construct) remaining in immunodepleted samples, and there was no signal in western blots against myc tag for immunodepleted samples (fig 1C). There was no difference in AMPK phosphorylation 
between uninfected and infected myotubes (fig 1D). Indicated molecular weights in this and other figures are the expected molecular weights of the products, not molecular weights of specific molecular weight markers. All proteins shown in blots ran to positions corresponding to their known sizes.

Infection with Ad-AMPK-CA resulted in a $70 \%$ increase of phosphorylation of an AMPK target, acetyl coenzyme A carboxylase (ACC, blot Fig.1E, quantitation Fig. 1E).

Phosphorylation of ACC was reduced in Ad-AMPK-DN infected cells.

In summary, these data demonstrate that the CA and DN forms of AMPK $\alpha$ were expressed and caused the expected changes in ACC phosphorylation.

\section{Regulation of insulin action by AMPK}

Expression of Ad-AMPK-CA increased 2-deoxyglucose (2-DG) uptake by approximately 50 $\%$ compared with the Ad-GFP controls (Fig. 2). Expression of Ad-AMPK-CA resulted in an approximately $60 \%$ increase of glucose transport in the presence of $10 \mathrm{nM}$ insulin and an approximately $70 \%$ increase in the presence of $100 \mathrm{nM}$ insulin. Thus, it appears that presence of active AMPK $\alpha 1$ is sufficient to increase insulin action.

A one hour treatment of myotubes with AICAR (followed by 4-h recovery) had a permissive effect on stimulation of glucose transport by insulin $(10 \mathrm{nM})$ in uninfected myotubes and myotubes expressing Ad-GFP but not in the Ad-AMPK-DN group (Fig. 3), such that prior AICAR treatment and exposure to insulin tended to have greater than additive effects on glucose transport.

The increase in insulin action caused by expression of Ad-AMPK-CA was suppressed after a 3-h treatment with compound C (Fig. 4A, with the corresponding GFP control data in Fig 4B), an AMPK inhibitor (40). In contrast, Compound $\mathrm{C}$ did not affect insulin action in cells transduced with Ad-GFP (Fig 4B). Glucose transport was increased by both $10 \mathrm{nM}$ insulin and $100 \mathrm{nM}$ insulin in myotubes expressing AMPK-CA (Fig 4A). In contrast, only $100 \mathrm{nM}$ insulin (but not $10 \mathrm{nM}$ insulin) increased glucose transport in cells transduced with Ad-GFP.

\section{Phosphorylation of S6K, IRS-1, and Akt}

In the Ad-AMPK-DN transduced C2C12 myotubes, S6K phosphorylation at threonine 389 (an mTOR target site) was significantly elevated by $63 \%(\mathrm{p}<0.05)$ compared to $\mathrm{C} 2 \mathrm{C} 12$ cells transfected with Ad-GFP (Fig. 5). Ad-AMPK-DN and Ad-AMPK-CA did not affect mTOR and S6K expression (Fig. 5A). Myotube content of GAPDH was not different among groups infected with the different viruses (Fig. 5C). These data suggest a posttranslational role for AMPK in mTOR regulation and are consistent with the previously-described role of AMPK as a negative regulator of mTOR (20).

Fig. 6 shows that transfection with Ad-AMPK-CA decreased IRS-1 phosphorylation at serine 636/639 (the mTOR and/or S6K target site), phosphorylation of which is associated with insulin resistance $(22 ; 29 ; 37)$. In contrast, transfection with Ad-AMPK-DN caused a 3.5 fold increase in IRS-1 phosphorylation at serine 636/639 (normalized to IRS-1 content), compared with AdGFP transfected C2C12 cells. IRS-1 protein expression was reduced in cells transduced with Ad-AMPK-DN, though expression of AMPK-CA did not significantly increase IRS-1 protein content.

Compared to Ad-GFP controls, there was a 2-fold increase in Akt phosphorylation at threonine 308 (Fig. 7) in Ad-AMPK-CA transfected cells and a $65 \%$ decrease in Akt phosphorylation at threonine 308 in Ad-AMPK-DN. Phosphorylation of Akt at serine 473 was decreased by 
approximately $50 \%$ in Ad-AMPK-DN transfected $\mathrm{C} 2 \mathrm{C} 12$ myotubes vs. the control group, though Akt serine 473 phosphorylation was unaltered by transduction with Ad-AMPK-CA.

\section{AMPK-related changes in glucose transport are not paralleled by changes in GLUT4 content}

Subcellular localization of GLUT4 was evaluated by confocal fluorescence microscopy. As shown in Fig. 8, GLUT4 displayed punctate, intracellular localization in Ad-GFP (Fig. 8A) and Ad-AMPK-DN (Fig. 8C) transfected myotubes. In contrast, there was apparent localization of GLUT4 at the plasma membrane in cells expressing AMPK-CA. Western blotting showed that levels of GLUT4 did not differ among the three groups (Fig. 8D-E). This suggests that AMPK is involved in potentiation of insulin action, even in the absence of changes in GLUT4 content in these $\mathrm{C} 2 \mathrm{C} 12$ myotubes. Thus, the impacts of the AMPK forms on glucose transport shown in Fig. 2-4 are likely to be post-translational signaling events (which is consistent with the short time course for potentiation of insulin action by AICAR or the Compound C-related suppression of insulin action in cells expressing AMPK-CA) as opposed to effects mediated by changes in gene expression.

\section{Discussion}

In the current study we have investigated the role of AMPK in regulating insulin-stimulated glucose uptake by $\mathrm{C} 2 \mathrm{C} 12$ myotubes by using adenoviral-mediated expression of AMPK-CA and AMPK-DN mutant forms. In accordance with previous suggestive findings $(5 ; 16 ; 35)$, it appears that AMPK activation positively regulates insulin action. Our findings indicate that activated AMPK $\alpha 1$ [that is known to be activated by multiple models of cellular stress, including muscle contractions, AICAR, and mitochondrial uncoupling $(8 ; 19)]$ was sufficient to increase insulin action. Additionally, incubation with an AMPK inhibitor suppressed the increased insulin action associated with expression of AMPK-CA. Furthermore, an inactive form of AMPK that depleted endogenous AMPK $\alpha$ prevented potentiation of insulin action by AICAR.

AICAR is not necessarily specific for activation of AMPK, because it activates AMPK after the intracellular conversion of AICAR to ZMP, an AMP analog. Thus, any pathway that is affected by AMP could theoretically also be affected by AICAR. While reported actions of Compound $\mathrm{C}$ are consistent with inhibition of AMPK [see Discussion in reference (35)], selectivity of Compound $\mathrm{C}$ has so far only been screened against a small number of kinases structurally related to AMPK (40). In the current study, however, the combined use of chemicals and mutant AMPK forms (e.g. use of Compound $\mathrm{C}$ to block effects of constitutively active AMPK use of dominant negative AMPK to prevent the effects of AICAR) helps in drawing firmer conclusions about the role of AMPK in regulation of insulin action than use of either the chemicals or mutant AMPK forms by themselves.

The experiment involving incubation of myotubes with AICAR was designed to probe the potential role of AMPK in insulin sensitivity that is apparent a few hours after an AMPKactivating treatment (e.g. incubation with AICAR, exercise, or incubation in hyperosmotic medium). For example, increased insulin sensitivity after exercise does not necessarily develop immediately (28) but may require a few hours to develop, even though the effect is not dependent on protein synthesis (5). Likewise, insulin action is not increased immediately after incubation of myotubes with hyperosmotic medium (an AMPK-activating treatment), but it is apparent after a few hours of recovery after incubation in hyperosmotic medium (35).

The current data complement and extend previous findings from studies involving animals. For example, AICAR increases insulin-stimulated glucose transport in rat skeletal muscle (5; 16), suggesting a possible role for AMPK in regulation of insulin action. On the other hand, insulin responsiveness (with $\sim 2 \mathrm{mU} / \mathrm{ml}$ insulin) of isolated skeletal muscle is not dampened 
in mice expressing AMPK-DN in skeletal muscle (that completely depletes endogenous active AMPK) or in whole-body AMPK $\alpha 2$ knockout mice (38). Additionally, an AMPK $\gamma$ knockout mouse has normal insulin sensitivity $(60 \mu \mathrm{U} / \mathrm{ml}$ insulin) and responsiveness ( $2 \mathrm{mU} / \mathrm{ml}$ insulin) in rested animals, and insulin responsiveness ( $\sim 2 \mathrm{mU} / \mathrm{ml}$ insulin) after exercise for the AMPK $\gamma$ knockout animals was the same as for wild-type animals $(1 ; 2)$. However, if, as has been suggested, AMPK is responsible for exercise-related increases in insulin action, it may (like exercise) have effects on insulin sensitivity but not necessarily insulin responsiveness $(9 ; 10)$ [though exercise sometimes also increases effects of extremely high insulin concentrations, e.g. (31)].

In our hands, Compound $\mathrm{C}$ did not reduce stimulation of glucose transport by insulin. Thus, it appears that though activation of AMPK potentiates insulin action, inhibition of basal AMPK activity does not reduce insulin action. This is analogous to the role of AMPK in stimulation of insulin-independent glucose transport: although activation of AMPK increases glucose transport, decreased basal AMPK activity (as a result of AMPK $\alpha$ knockout or inactive forms of AMPK $\alpha$ ) reportedly does not decrease basal glucose transport $(8 ; 19 ; 26)$.

It is important to the interpretation of the increased insulin action in myotubes transduced with AMPK-CA that GLUT4 content of myotubes was not altered by AMPK-CA. In this regard, the increased insulin action related to AMPK-CA is similar to exercise-related increases in insulin sensitivity, that occur before GLUT4 has increased after exercise (12) and even when post-exercise protein synthesis is inhibited (5). Long-term (5 days) expression of constitutively-active AMPK in myotubes reportedly increases GLUT4 (6), so perhaps AMPKCA was not expressed long enough in our short-term study (2 days) for GLUT4 to be increased. Interestingly, there is reportedly no alteration in GLUT4 content in mice expressing AMPKDN (the same construct as is used in the current study) in skeletal muscle (26). Similarly, GLUT4 expression is not dampened in muscles of AMPK $\alpha 1$ or AMPK $\alpha 2$ knockout mice or in mice expressing inactive AMPK $\alpha 2(8 ; 19)$.

Recent studies suggest a possible linkage between AMPK and insulin signaling pathways and that the mTOR/S6K pathway may play an important role in regulation of insulin signaling (20). The current data showing a role for AMPK in regulation of serine phosphorylation of IRS-1 (at an mTOR or S6K target site) is consistent with the postulated role for AMPK in acute regulation of insulin action $(5 ; 16)$. mTOR exists in two distinct complexes: one that contains

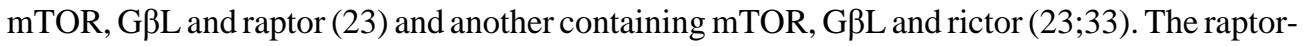
containing complex is sensitive to the drug rapamycin and phosphorylates S6K (3), and the rictor-containing complex does not appear to be rapamycin-sensitive (33). It has been demonstrated that mTOR-rictor directly phosphorylates Akt on Ser473; mTOR-rictor is the Akt serine 473 kinase that is associated with insulin signaling in adipocytes, and a reduction in rictor or mTOR expression inhibits Akt (15;34). Although there is an absence of data in regard to regulation of mTOR-rictor, it is tempting to hypothesize that activation of AMPK could have differential effects on mTOR.rictor (an Akt serine 473 kinase) and mTOR.raptor (that mediates serine phosphorylation of IRS-1).

It has been known for about 20 years that exercise increases insulin sensitivity in skeletal muscle in rats (31), and similar findings have just been reported for mice (11). In humans, insulin action is increased a few hours after exercise (25) and stays elevated for up to two days $(25 ; 30)$. Based on the current findings, it seems possible that activation of AMPK contributes to at least part of the increase in insulin action after exercise, especially the acute increase in insulin sensitivity (25) that occurs even in the absence of protein synthesis (5).

In summary, the data presented here suggest that in myotubes AMPK regulates insulin action and also hint that changes in insulin action caused by AMPK in myotubes may occur through 
decreased serine phosphorylation of IRS-1 by mTOR/S6K. These findings suggest that similar studies should be undertaken to determine whether activation of AMPK affects insulin action in animal muscle.

\section{Acknowledgements}

This work was supported by National Institutes of Health K01 DK066330 (JSF), and some funding for supplies was provided by the Saint Louis University Beaumont Faculty Development Fund. Confocal microscopy was made possible by National Science Foundation Division of Biological Infrastructure Major Instrumentation Award \#0421383 (SAS). Alyssa A. Mielke, LaQuinta R. Lewis, and James Kain Ching provided technical assistance.

\section{References}

1. Barnes BR, Long YC, Steiler TL, Leng Y, Galuska D, Wojtaszewski JF, Andersson L, Zierath JR. Changes in Exercise-Induced Gene Expression in 5'-AMP-Activated Protein Kinase \{gamma\}3-Null and \{gamma\}3 R225Q Transgenic Mice. Diabetes 2005;54:3484-3489. [PubMed: 16306365]

2. Barnes BR, Marklund S, Steiler TL, Walter M, Hjalm G, Amarger V, Mahlapuu M, Leng Y, Johansson C, Galuska D, Lindgren K, Abrink M, Stapleton D, Zierath JR, Andersson L. The 5'-AMP-activated protein kinase gamma3 isoform has a key role in carbohydrate and lipid metabolism in glycolytic skeletal muscle. J Biol Chem 2004;279:38441-38447. [PubMed: 15247217]

3. Burnett PE, Barrow RK, Cohen NA, Snyder SH, Sabatini DM. RAFT1 phosphorylation of the translational regulators p70 S6 kinase and 4E-BP1. Proc Natl Acad Sci U S A 1998;95:1432-1437. [PubMed: 9465032]

4. Fisher JS. Potential role of the AMP-activated protein kinase in regulation of insulin action. Cellscience Reviews (ISSN 1742-8130) 2006;2(3) http://www.cellscience.com/reviews7/AMP_kinase_insulin.html,

5. Fisher JS, Gao J, Han DH, Holloszy JO, Nolte LA. Activation of AMP kinase enhances sensitivity of muscle glucose transport to insulin. Am J Physiol Endocrinol Metab 2002;282:E18-E23. [PubMed: 11739078]

6. Fryer LG, Foufelle F, Barnes K, Baldwin SA, Woods A, Carling D. Characterization of the role of the AMP-activated protein kinase in the stimulation of glucose transport in skeletal muscle cells. Biochem J 2002;363:167-174. [PubMed: 11903059]

7. Fujii N, Aschenbach WG, Musi N, Hirshman MF, Goodyear LJ. Regulation of glucose transport by the AMP-activated protein kinase. Proc Nutr Soc 2004;63:205-210. [PubMed: 15294031]

8. Fujii N, Hirshman MF, Kane EM, Ho RC, Peter LE, Seifert MM, Goodyear LJ. AMP-activated protein kinase alpha2 activity is not essential for contraction-and hyperosmolarity-induced glucose transport in skeletal muscle. J Biol Chem. 2005

9. Garetto LP, Richter EA, Goodman MN, Ruderman NB. Enhanced muscle glucose metabolism after exercise in the rat: the two phases. Am J Physiol 1984;246:E471-E475. [PubMed: 6377909]

10. Gulve EA, Cartee GD, Zierath JR, Corpus VM, Holloszy JO. Reversal of enhanced muscle glucose transport after exercise: roles of insulin and glucose. Am J Physiol 1990;259:E685-E691. [PubMed: 2240207]

11. Hamada T, Arias EB, Cartee GD. Increased submaximal insulin-stimulated glucose uptake in mouse skeletal muscle after treadmill exercise. J Appl Physiol. 2006

12. Hansen PA, Nolte LA, Chen MM, Holloszy JO. Increased GLUT-4 translocation mediates enhanced insulin sensitivity of muscle glucose transport after exercise. J Appl Physiol 1998;85:1218-1222. [PubMed: 9760308]

13. Hardie DG. The AMP-activated protein kinase pathway--new players upstream and downstream. J Cell Sci 2004;117:5479-5487. [PubMed: 15509864]

14. Harrington LS, Findlay GM, Gray A, Tolkacheva T, Wigfield S, Rebholz H, Barnett J, Leslie NR, Cheng S, Shepherd PR, Gout I, Downes CP, Lamb RF. The TSC1-2 tumor suppressor controls insulin-PI3K signaling via regulation of IRS proteins. J Cell Biol 2004;166:213-223. [PubMed: 15249583]

15. Hresko RC, Mueckler M. mTOR/RICTOR is the Ser473 kinase for Akt/PKB in 3T3-L1 adipocytes. J Biol Chem. 2005 
16. Iglesias MA, Ye JM, Frangioudakis G, Saha AK, Tomas E, Ruderman NB, Cooney GJ, Kraegen EW. AICAR administration causes an apparent enhancement of muscle and liver insulin action in insulinresistant high-fat-fed rats. Diabetes 2002;51:2886-2894. [PubMed: 12351423]

17. Inoki K, Li Y, Zhu T, Wu J, Guan KL. TSC2 is phosphorylated and inhibited by Akt and suppresses mTOR signalling. Nat Cell Biol 2002;4:648-657. [PubMed: 12172553]

18. Inoki K, Zhu T, Guan KL. TSC2 mediates cellular energy response to control cell growth and survival. Cell 2003;115:577-590. [PubMed: 14651849]

19. Jorgensen SB, Viollet B, Andreelli F, Frosig C, Birk JB, Schjerling P, Vaulont S, Richter EA, Wojtaszewski JF. Knockout of the alpha2 but not alpha1 5'-AMP-activated protein kinase isoform abolishes 5-aminoimidazole-4-carboxamide-1-beta-4-ribofuranosidebut not contraction-induced glucose uptake in skeletal muscle. J Biol Chem 2004;279:1070-1079. [PubMed: 14573616]

20. Kahn BB, Alquier T, Carling D, Hardie DG. AMP-activated protein kinase: ancient energy gauge provides clues to modern understanding of metabolism. Cell Metab 2005;1:15-25. [PubMed: 16054041]

21. Kimura N, Tokunaga C, Dalal S, Richardson C, Yoshino K, Hara K, Kemp BE, Witters LA, Mimura $\mathrm{O}$, Yonezawa K. A possible linkage between AMP-activated protein kinase (AMPK) and mammalian target of rapamycin (mTOR) signalling pathway. Genes Cells 2003;8:65-79. [PubMed: 12558800]

22. Li J, DeFea K, Roth RA. Modulation of insulin receptor substrate-1 tyrosine phosphorylation by an Akt/phosphatidylinositol 3-kinase pathway. J Biol Chem 1999;274:9351-9356. [PubMed: 10092613]

23. Loewith R, Jacinto E, Wullschleger S, Lorberg A, Crespo JL, Bonenfant D, Oppliger W, Jenoe P, Hall MN. Two TOR complexes, only one of which is rapamycin sensitive, have distinct roles in cell growth control. Mol Cell 2002;10:457-468. [PubMed: 12408816]

24. Merrill GF, Kurth EJ, Hardie DG, Winder WW. AICA riboside increases AMP-activated protein kinase, fatty acid oxidation, and glucose uptake in rat muscle. Am J Physiol 1997;273:E1107-E1112. [PubMed: 9435525]

25. Mikines KJ, Sonne B, Farrell PA, Tronier B, Galbo H. Effect of physical exercise on sensitivity and responsiveness to insulin in humans. Am J Physiol 1988;254:E248-E259. [PubMed: 3126668]

26. Mu J, Brozinick JT Jr. Valladares O, Bucan M, Birnbaum MJ. A role for AMP-activated protein kinase in contraction- and hypoxia-regulated glucose transport in skeletal muscle. Mol Cell 2001;7:1085-1094. [PubMed: 11389854]

27. Nagata D, Mogi M, Walsh K. AMP-activated protein kinase (AMPK) signaling in endothelial cells is essential for angiogenesis in response to hypoxic stress. J Biol Chem 2003;278:31000-31006. [PubMed: 12788940]

28. Nesher R, Karl IE, Kipnis DM. Dissociation of effects of insulin and contraction on glucose transport in rat epitrochlearis muscle. Am J Physiol 1985;249:C226-C232. [PubMed: 3898861]

29. Ozes ON, Akca H, Mayo LD, Gustin JA, Maehama T, Dixon JE, Donner DB. A phosphatidylinositol 3-kinase/Akt/mTOR pathway mediates and PTEN antagonizes tumor necrosis factor inhibition of insulin signaling through insulin receptor substrate-1. Proc Natl Acad Sci U S A 2001;98:4640-4645. [PubMed: 11287630]

30. Perseghin G, Price TB, Petersen KF, Roden M, Cline GW, Gerow K, Rothman DL, Shulman GI. Increased glucose transport-phosphorylation and muscle glycogen synthesis after exercise training in insulin-resistant subjects. N Engl J Med 1996;335:1357-1362. [PubMed: 8857019]

31. Richter EA, Garetto LP, Goodman MN, Ruderman NB. Muscle glucose metabolism following exercise in the rat: increased sensitivity to insulin. J Clin Invest 1982;69:785-793. [PubMed: 6804492]

32. Rutter GA, Da S,X, Leclerc I. Roles of 5'-AMP-activated protein kinase (AMPK) in mammalian glucose homoeostasis. Biochem J 2003;375:1-16. [PubMed: 12839490]

33. Sarbassov DD, Ali SM, Kim DH, Guertin DA, Latek RR, Erdjument-Bromage H, Tempst P, Sabatini DM. Rictor, a novel binding partner of $\mathrm{mTOR}$, defines a rapamycin-insensitive and raptorindependent pathway that regulates the cytoskeleton. Curr Biol 2004;14:1296-1302. [PubMed: 15268862]

34. Sarbassov DD, Guertin DA, Ali SM, Sabatini DM. Phosphorylation and regulation of Akt/PKB by the rictor-mTOR complex. Science 2005;307:1098-1101. [PubMed: 15718470] 
35. Smith JL, Patil PB, Fisher JS. AICAR and hyperosmotic stress increase insulin-stimulated glucose transport. J Appl Physiol 2005;99:877-883. [PubMed: 15860681]

36. Smith JL, Patil PB, Minteer SD, Lipsitz JR, Fisher JS. Possibility of autocrine beta-adrenergic signaling in C2C12 myotubes. Exp Biol Med (Maywood) 2005;230:845-852. [PubMed: 16339749]

37. Um SH, Frigerio F, Watanabe M, Picard F, Joaquin M, Sticker M, Fumagalli S, Allegrini PR, Kozma SC, Auwerx J, Thomas G. Absence of S6K1 protects against age- and diet-induced obesity while enhancing insulin sensitivity. Nature 2004;431:200-205. [PubMed: 15306821]

38. Viollet B, Andreelli F, Jorgensen SB, Perrin C, Geloen A, Flamez D, Mu J, Lenzner C, Baud O, Bennoun M, Gomas E, Nicolas G, Wojtaszewski JF, Kahn A, Carling D, Schuit FC, Birnbaum MJ, Richter EA, Burcelin R, Vaulont S. The AMP-activated protein kinase alpha2 catalytic subunit controls whole-body insulin sensitivity. J Clin Invest 2003;111:91-98. [PubMed: 12511592]

39. Zang M, Zuccollo A, Hou X, Nagata D, Walsh K, Herscovitz H, Brecher P, Ruderman NB, Cohen RA. AMP-activated protein kinase is required for the lipid-lowering effect of metformin in insulinresistant human HepG2 cells. J Biol Chem 2004;279:47898-47905. [PubMed: 15371448]

40. Zhou G, Myers R, Li Y, Chen Y, Shen X, Fenyk-Melody J, Wu M, Ventre J, Doebber T, Fujii N, Musi N, Hirshman MF, Goodyear LJ, Moller DE. Role of AMP-activated protein kinase in mechanism of metformin action. J Clin Invest 2001;108:1167-1174. [PubMed: 11602624]

41. Zou MH, Hou XY, Shi CM, Nagata D, Walsh K, Cohen RA. Modulation by peroxynitrite of Aktand AMP-activated kinase-dependent Ser1179 phosphorylation of endothelial nitric oxide synthase. J Biol Chem 2002;277:32552-32557. [PubMed: 12107173] 
A.

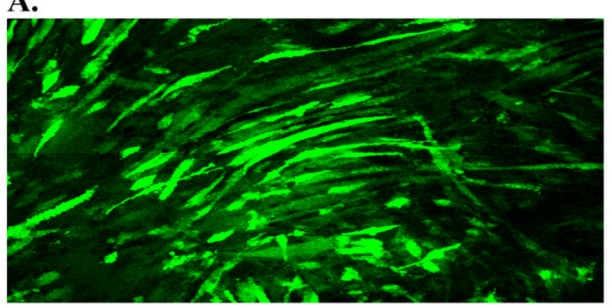

B.

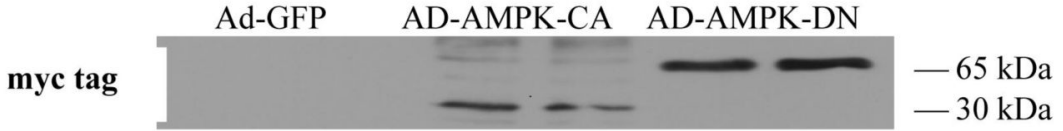

AMPK $\alpha$

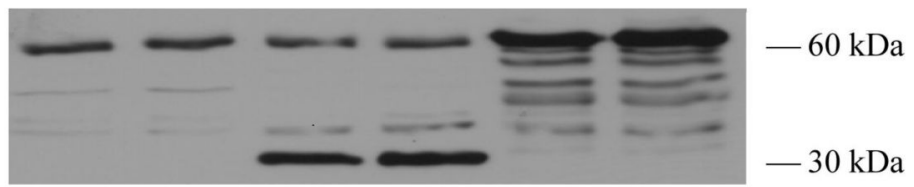

GAPDH

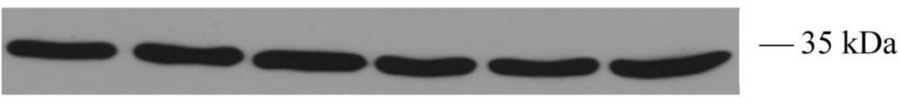

C.

samples after myc tag immunodepletion

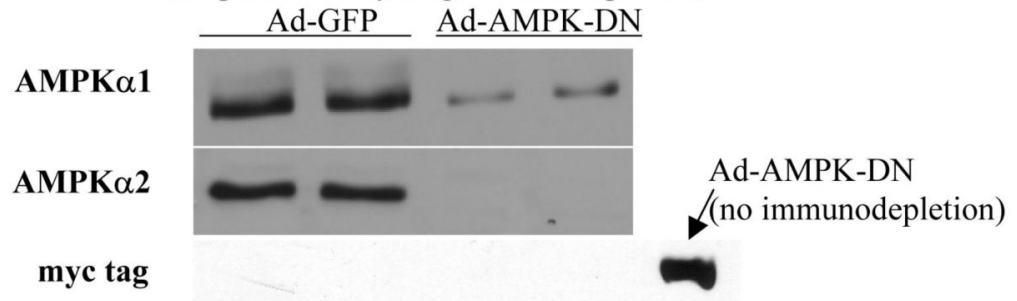

D.

P-AMPK $\alpha$

No virus Ad-GFP Ad-AMPK-CA Ad-AMPK-DN

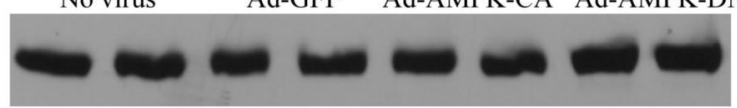

AMPK $\alpha$

AMPK $\alpha 1$

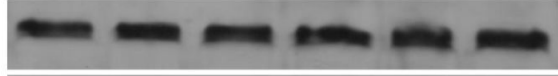

AMPK $\alpha 2$

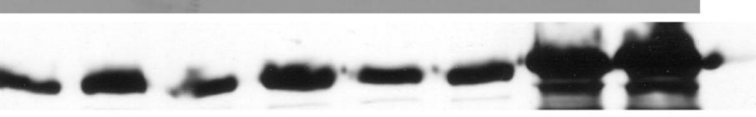


E.

P-ACC

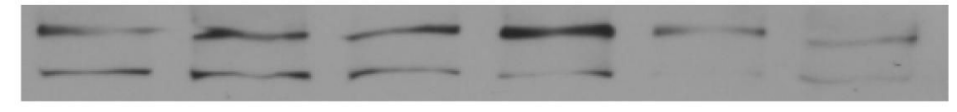

$-280 \mathrm{kDa}$

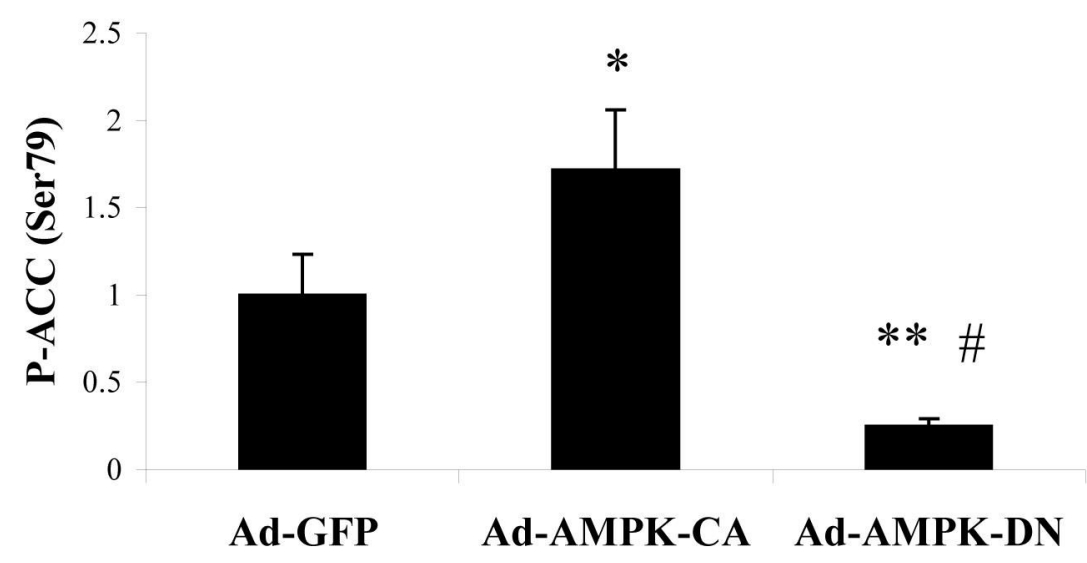

Fig.1.

Adenovirus-mediated expression of Ad-AMPK-CA and Ad-AMPK-DN in C2C12 myotubes. (A) Confocal microscopic visualization of C2C12 myotubes infected with Ad-GFP (100 pfu/ cell, 2 days). (B) Lysates from cells infected with adenovirus (100 pfu/cell, 2 days) containing GFP for control or a constitutively active mutant of AMPK or a dominant-negative mutant were analyzed by Western blotting using anti- $\alpha$-myc, anti-AMPK $\alpha$, and anti-GAPDH antibodies. (C) Lysates from cells infected with Ad-GFP or a dominant-negative mutant were immunoprecipitated with antibodies against myc epitope, and immunodepleted supernatants then were analyzed by Western blotting using anti-AMPK $\alpha 1$ and anti-AMPK $\alpha 2$. Effectiveness of immunodepletion of myc-tagged proteins was assessed with a western blot using antibodies against myc tag with a non-immunodepleted sample from Ad-AMPK-DN cells (loaded with the same amount of protein as the immunodepleted samples) as a positive control for presence of myc epitope. (D) Effects of adenovirus-mediated expression of AMPK-CA and AMPK-DN on AMPK phosphorylation and AMPK content. As controls, some myotubes were not infected with virus. (E): densitometry of phosphorylation of ACC. Phosphorylation of ACC was determined by Western analysis with phospho-ACC (Ser79)-specific antibody. Values are means $\pm \mathrm{SE} ; \mathrm{n}=16$ in each group. ${ }^{*} \mathrm{P}<0.05$ and $* * \mathrm{P}<0.05 \mathrm{vs}$. Ad-GFP; \#P<0.05 vs. Ad-AMPKCA. 


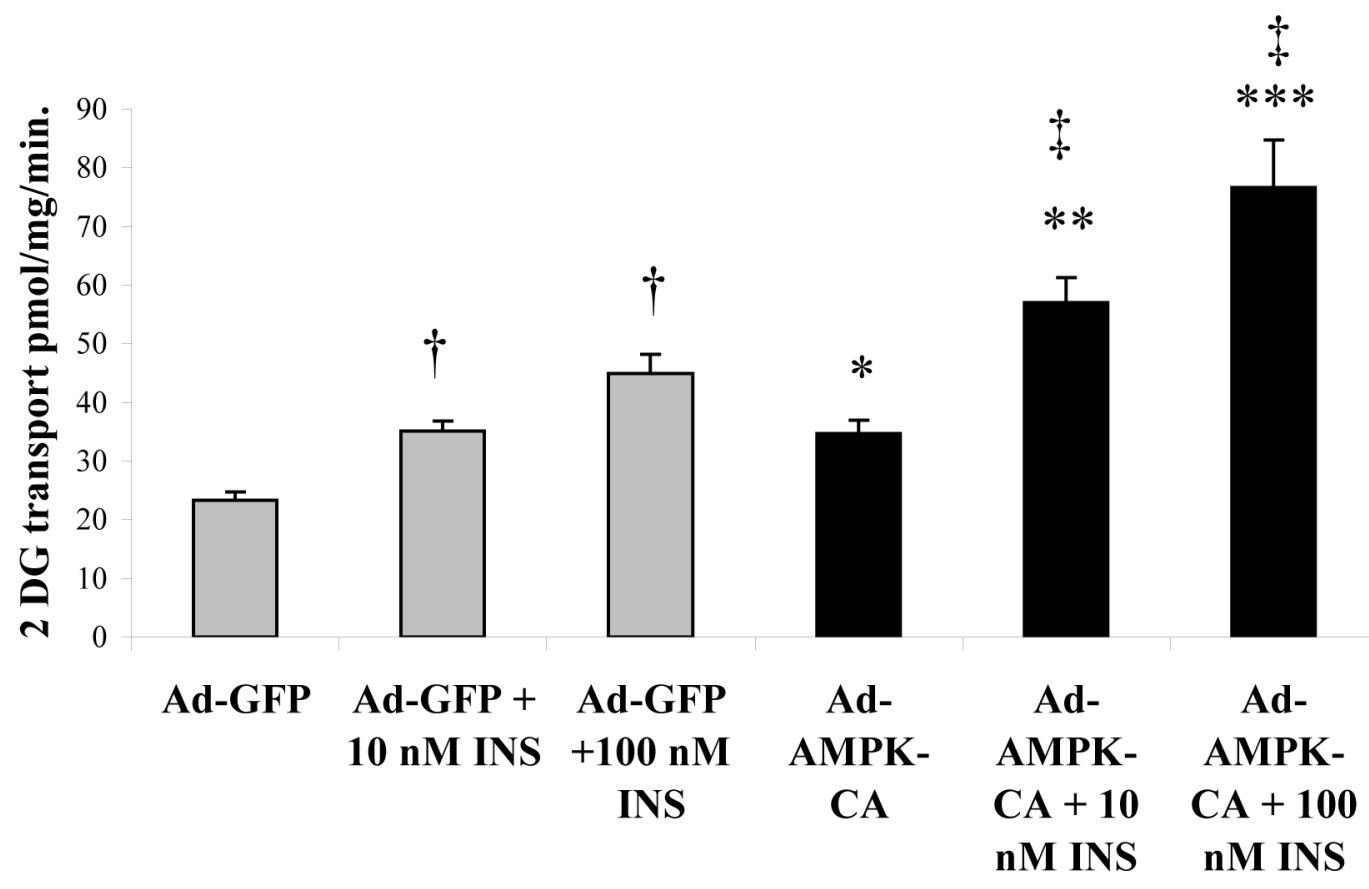

Fig.2.

Effect of Ad-AMPK-CA expression on glucose uptake. 2-deoxyglucose (2-DG) uptake was assayed in C2C12 myotubes transduced with Ad-GFP and Ad-AMPK-CA (100 p.f.u./cell, 2 days) in the absence or presence of $10 \mathrm{nM}$ or $100 \mathrm{nM}$ insulin. Values are means $\pm \mathrm{SE}$. *, **, and $* * *$ : These values are significantly different $(\mathrm{p}<0.05)$ from glucose uptake rate in corresponding Ad-GFP control groups. † $\dagger$ significantly different from corresponding control without insulin $(\mathrm{P}<0.05)$. $¥$ significantly different from corresponding control without insulin $(\mathrm{P}<0.001)$. $\mathrm{N}=6-12 /$ group. 


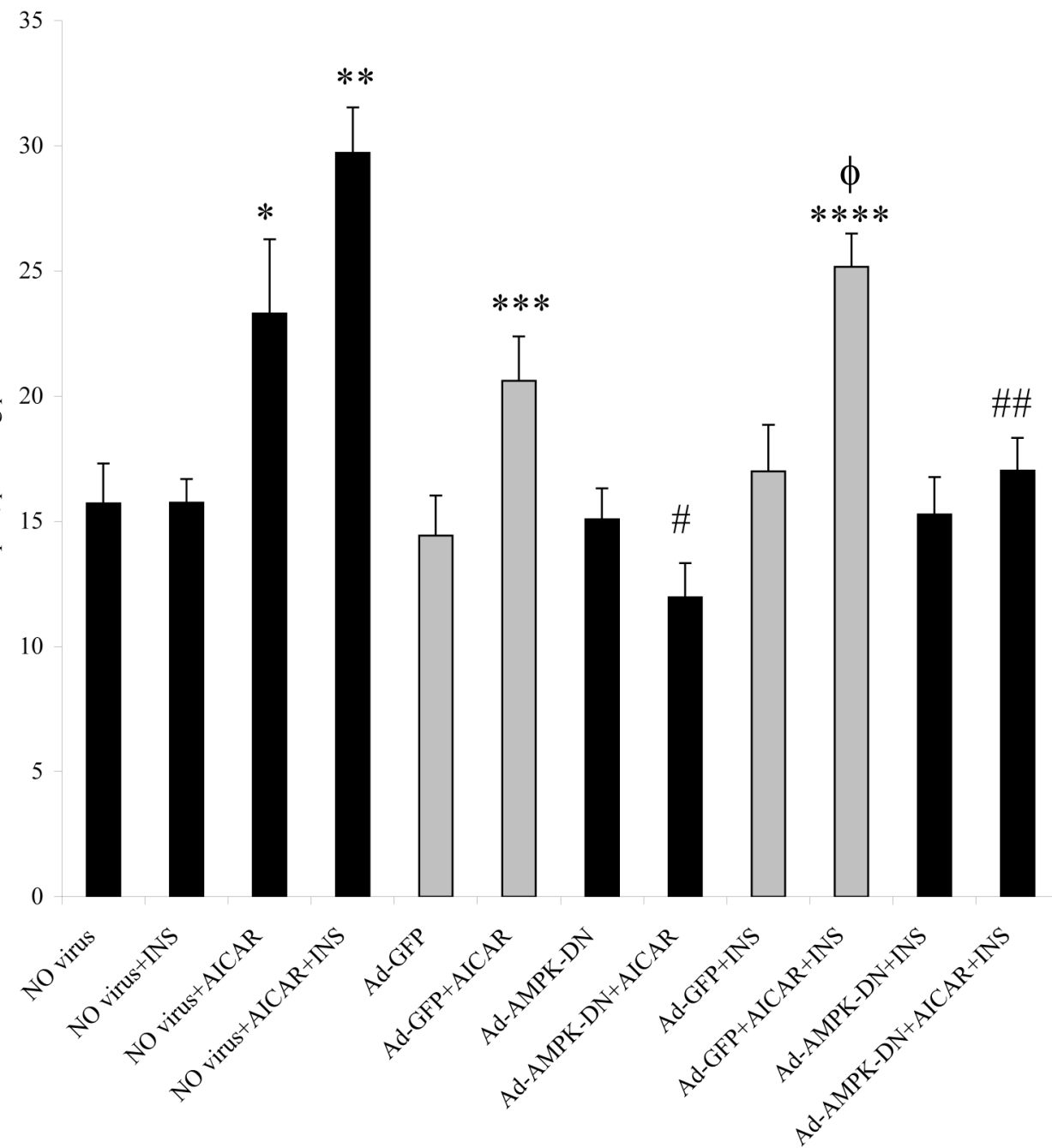

Fig 3.

Effects of Ad-AMPK-DN expression and AICAR on glucose uptake. Cells not infected with virus or cells infected with Ad-GFP or Ad-AMPK-DN were incubated with or without $0.5 \mathrm{mM}$ AICAR for $1 \mathrm{~h}$. After a $4 \mathrm{~h}$ recovery, 2-deoxyglucose (2-DG) uptake was then assayed in the absence or presence of $10 \mathrm{nM}$ insulin. Values are means $\pm \mathrm{SE}$. $* \mathrm{P}<0.05$ vs. No virus and No virus + insulin; $* * \mathrm{P}<0.05$ vs. No virus, No virus + insulin, and No virus $+\mathrm{AICAR} ; * * * \mathrm{P}<0.05$ vs. Ad-GFP; $* * * * P<0.05$ vs. Ad-GFP + insulin; $\# \mathrm{P}<0.05$ vs. Ad-GFP + AICAR; \#\#P<0.05 vs. Ad-GFP + AICAR + insulin; $\varphi \mathrm{P}<0.05$ vs. Ad-GFP + AICAR. N=6/group. 
A.
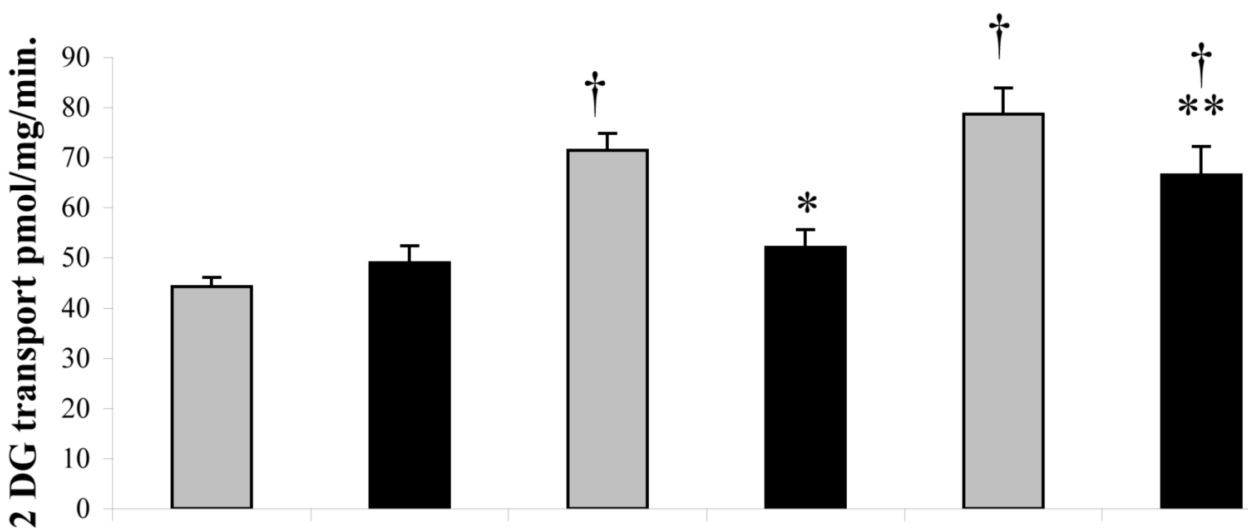

Ad-

Ad-

Ad-

Ad-

Ad-

Ad-

AMPK-CA

AMPK-

AMPK-

AMPK-

AMPK-

AMPK-

$\mathrm{CA}+\mathrm{Com} \mathrm{CA}+10 \mathrm{nM} \mathrm{CA}+\mathrm{Com}$

$\mathrm{CA}+100$

CA+Com

C

INS

$\mathrm{C}+10 \mathrm{nM}$

nM INS

INS

$\mathrm{C}+100 \mathrm{nM}$

INS

B.
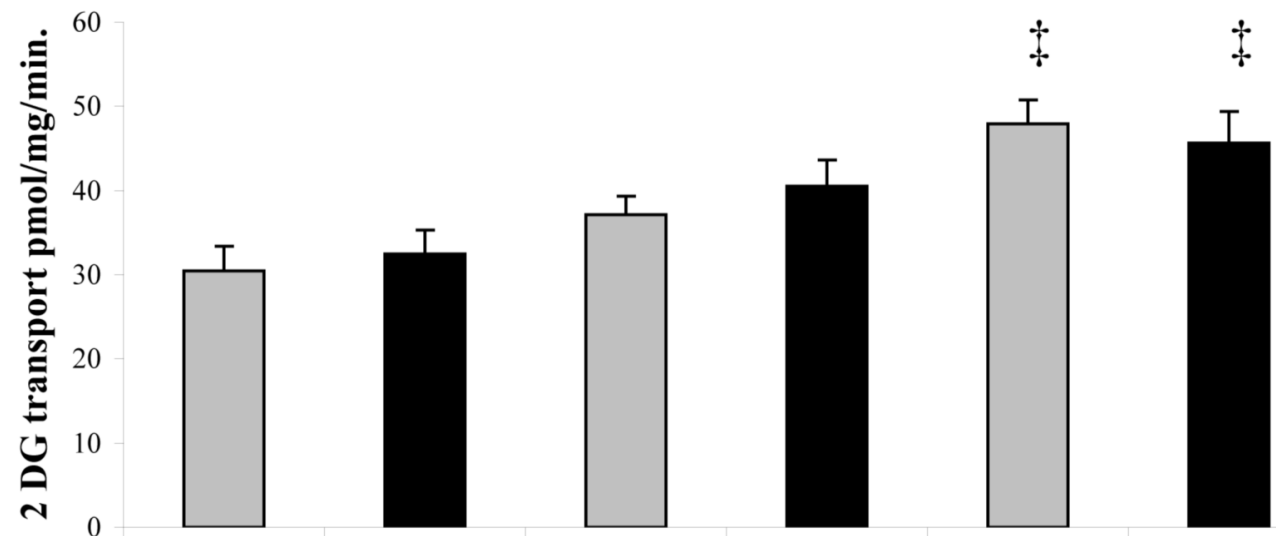

Ad-GFP
Ad-GFP + $\operatorname{com} \mathrm{C}$

Ad-GFP

Ad-GFP +

A

$100 \mathrm{nM}$

Ad-GFP +

\section{nM INS}

INS

\section{$100 \mathrm{nM}$}

INS

Fig. 4.

Effects of Ad-AMPK-CA expression and Compound C on glucose uptake. (A) C2C12 myotubes infected with Ad-AMPK-CA (100 p.f.u./cell, 2 days) were incubated with or without $20 \mu \mathrm{M}$ Compound $\mathrm{C}$ (an AMPK inhibitor) for $3 \mathrm{~h}$ before measurement of 2-deoxyglucose (2DG) uptake. $\dagger$ These means were significantly different $(\mathrm{P}<0.005)$ from means for groups that were not treated with insulin. ${ }^{*}, *$ These values are significantly different $(\mathrm{p}<0.05)$ from corresponding insulin-stimulated glucose uptake rates for cells that were not pre-treated with the inhibitor. $\mathrm{N}=25-32 /$ group. (B) C2C12 myotubes infected with Ad-GFP (100 p.f.u./cell, 2 days) were incubated with or without $20 \mu \mathrm{M}$ Compound $\mathrm{C}$ for $3 \mathrm{~h}$ before measurement of 2- 
DG uptake. $\ddagger$ significantly different $(\mathrm{P}<0.01)$ from means for groups not treated with insulin. $\mathrm{N}=12-18$ /group. Values are means $\pm \mathrm{SE}$. 
A.

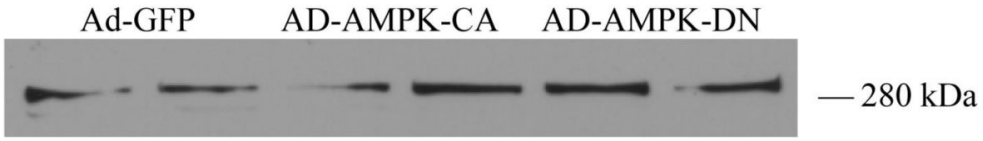

P-p85S6K

P-p70S6K

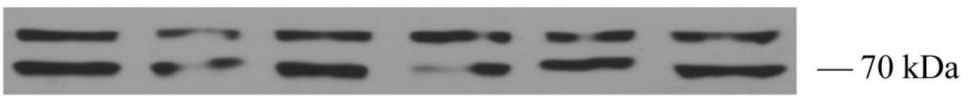

p70S6k

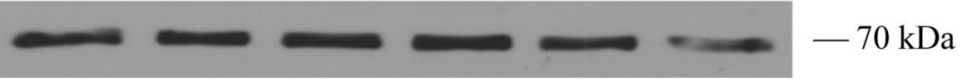

B.

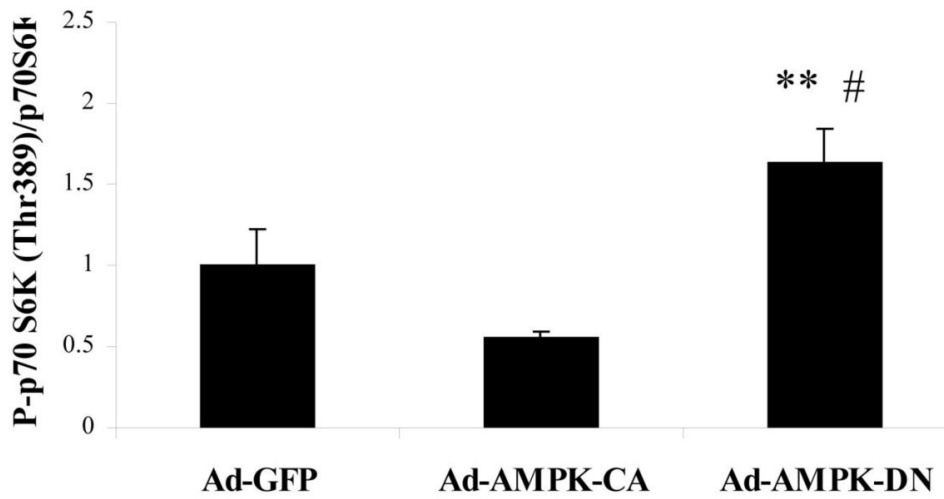

C.

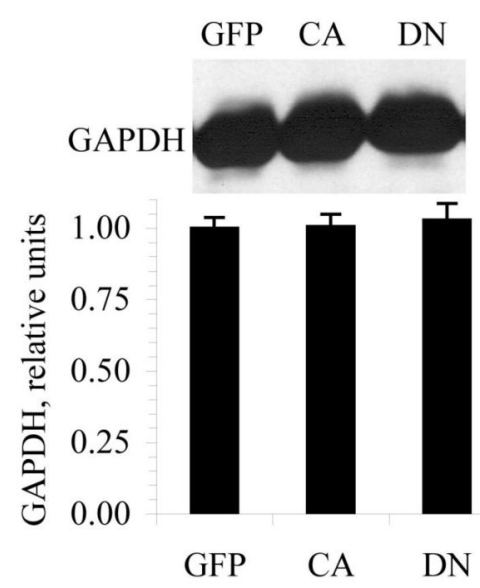

Fig. 5.

Effects of Adenovirus-mediated expression of AMPK-CA and AMPK-DN on the phosphorylation of S6k. (A): representative mTOR (top), phospho-S6k (middle) and S6k (bottom) Western blot samples. (B): densitometry of phosphorylation of S6k at Thr389 (the mTOR target site). Each sample was normalized to the S6K band and the densities were calculated. C) GAPDH content of myotubes transduced with Ad-GFP, Ad-AMPK-CA, and Ad-AMPK-DN. For A and B, N=16 in each group. ${ }^{* * P}<0.05$ vs. Ad-GFP; $\# \mathrm{P}<0.05$ vs. AdAMPK-CA. For $\mathrm{C}, \mathrm{N}=8 /$ group. Values are means $\pm \mathrm{SE}$. 
A.

B.

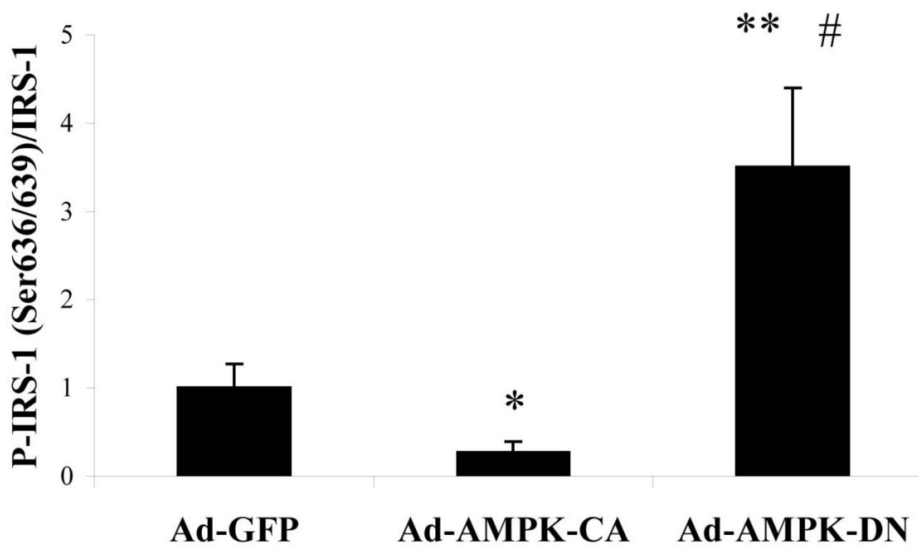

C.

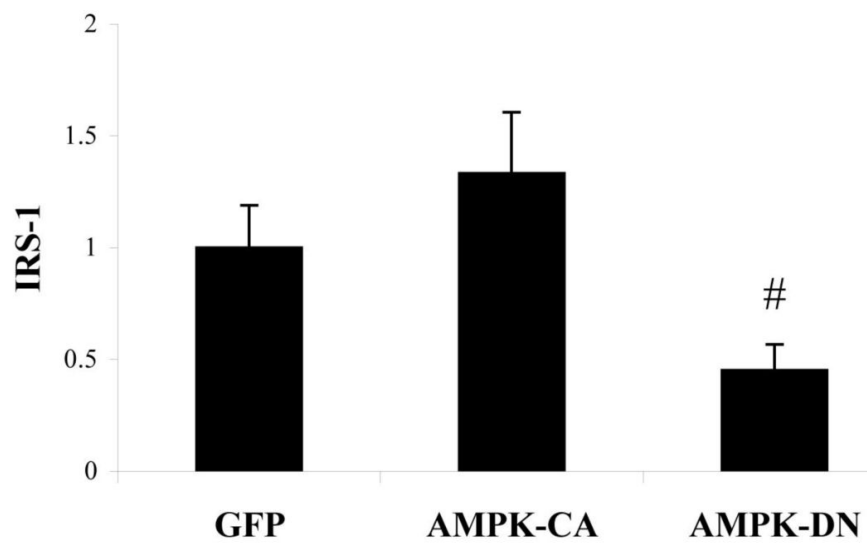

Fig. 6.

Effects of Adenovirus-mediated expression of AMPK-CA and AMPK-DN on the phosphorylation of IRS-1 and IRS-1 protein expression. (A): representative phospho-IRS-1 (top) and IRS-1 (bottom) Western blot samples. (B): densitometry of phosphorylation of IRS-1 at Ser636/639. Each sample was normalized to total IRS- 1 . $* \mathrm{P}<0.05$ and $* * \mathrm{P}<0.05 \mathrm{vs}$. Ad-GFP; \#P $<0.05$ vs. Ad-AMPK-CA. (C): Akt protein content. Ad-GFP infected cell lysate (lane 1 and 2). \#P $<0.05$ vs. Ad-AMPK-CA. Ad-AMPK-CA infected cell lysate (lane 3 and 4 ), and AdAMPK-DN infected cell lysate (lanes 5 and 6 ). Values are means $\pm S E ; n=16$ in each group. 
A.

P-Akt-Ser473

P-Akt-Thr308

Akt

Ad-GFP AD-AMPK-CA AD-AMPK-DN
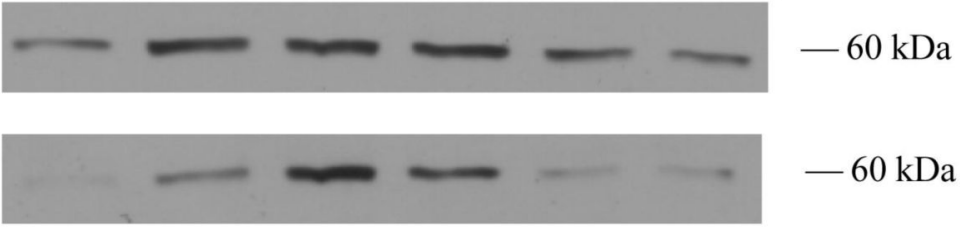

$-60 \mathrm{kDa}$

B.

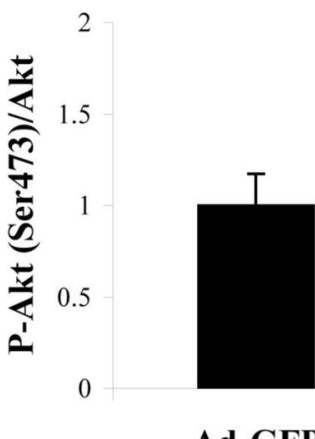

Ad-GFP

C.

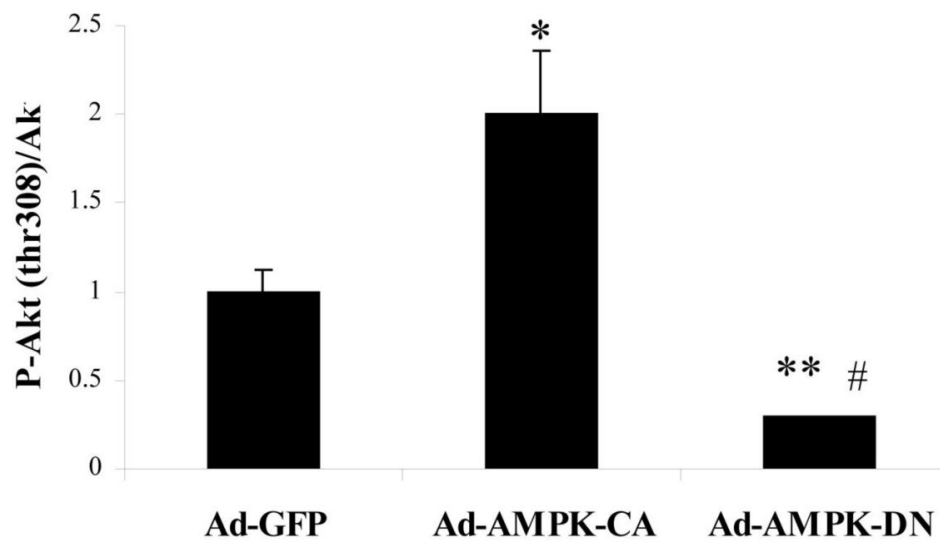

Fig. 7.

Representative blots and their densitometric quantification of effects of Ad-AMPK-CA and Ad-AMPK-DN on the phosphorylation of Akt. (A): representative phospho-Akt-Ser473 (top), phospho-Akt-Thr308 (middle), and Akt (bottom) Western blot samples. (B): densitometry of phosphorylation of Akt at Ser473. $* * \mathrm{P}<0.05 \mathrm{vs}$. Ad-GFP; \#P<0.05 vs. Ad-AMPK-CA. (C): densitometry of phosphorylation of Akt at Thr308. Each sample was normalized to total Akt. Ad-GFP infected cell lysate (lane 1 and 2), Ad-AMPK-CA infected cell lysate (lane 3 and 4), and Ad-AMPK-DN infected cell lysate (lanes 5 and 6 ). $* \mathrm{P}<0.05$ and $* * \mathrm{P}<0.05 \mathrm{vs}$. Ad-GFP; $\# \mathrm{P}<0.05$ vs. Ad-AMPK-CA. Values are means $\pm \mathrm{SE} ; \mathrm{n}=16$ in each group. 


\section{A. Ad-GFP}

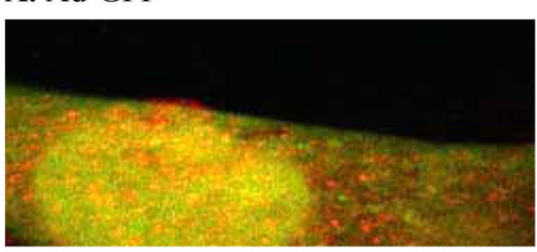

B. Ad-AMPK-CA

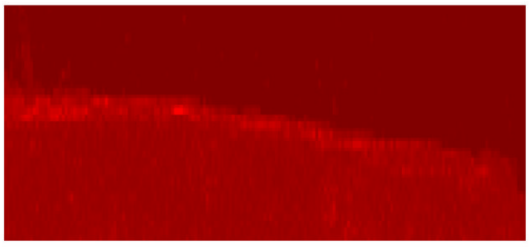

C. Ad-AMPK-DN

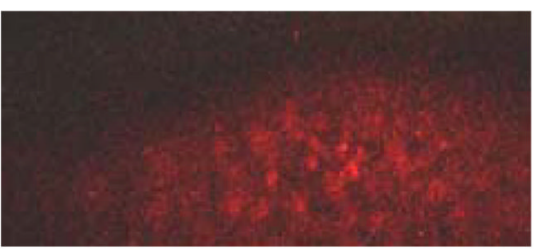

D.

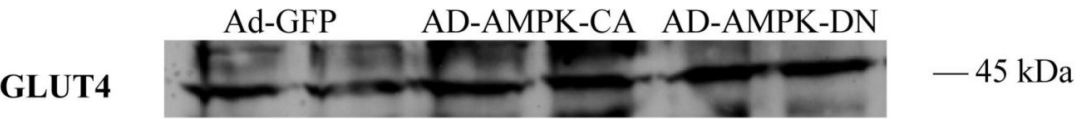

E.

2

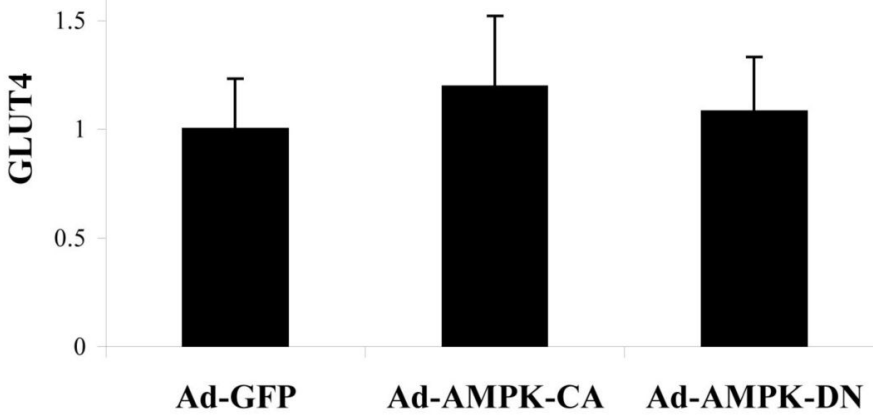

Fig. 8.

Effects of Adenovirus-mediated expression of AMPK-CA and AMPK-DN on GLUT4 translocation and protein expression. (A, B and C) Confocal microscopic visualization of the localization of GLUT4 in C2C12 myotubes. Representative fields of cells are shown: Ad-GFP infected cell (A), Ad-AMPK-CA infected cell (B), and Ad-AMPK-DN infected cell (C). (D): representative Glut4 Western blot samples. (E): densitometry of GLUT4 protein expression. Values are means $\pm S E ; n=12$ in each group. 